\title{
Ordinnlæringsstrategier i tysklærebøker
}

Johan Øye

Lyngdal ungdomsskole

\section{Sammendrag}

Dette bidraget undersøker ordinnlæringsøvelser i to lærebøker i tysk som fremmedspråk på nivå 1 på videregående skole. Utgangspunktet for undersøkelsen er vektleggingen av kommunikasjon og språklæringsstrategier i Laereplan i fremmedspråk i LK06.

Ordinnlæringsøvelsene blir kategorisert og analysert ut i fra hvilke læringsstrategier de representerer. Kategoriene som blir brukt er kognitive og metakognitive læringsstrategier med underkategorier. Bidraget konkluderer med at det er lite fokus på ordinnlæringsstrategier i lærebøkene som blir undersøkt. I oppgavene som eksplisitt handler om å lære nye ord blir eleven ofte bedt om å øve, repetere eller lære inn ordene før de skal tas i bruk i en skriftlig eller muntlig øvelse. Det blir imidlertid ikke presentert noen strategier for ordinnlæringen. Mangelen på oppgaver som representerer visualisering, assosiering og strukturering bekrefter dette inntrykket. En av lærebøkene inneholder en undersøkelse som skal hjelpe elevene å finne ut hvordan de liker å lære. Dette kunne ha vært fulgt opp i større grad når det gjelder ordinnlæring.

Denne teksten er en bearbeidet versjon av en undersøkelse som ble utført innenfor rammene av studiet PPU med fagdidaktikk i tysk ved Universitetet i Agder.

\section{Nøkkelord}

Ordinnlæring, fremmedspråk, tysk, læringsstrategier, lærebøker 


\section{Nordic Journal of Modern Language Methodology}

2019, 7 (1), 84-115 (Part B - Not peer reviewed)

\section{En liten fortelling}

Det er torsdag og matfri. Jeg tar en bit av hornet med smeltet ost og prøver å finne riktig side i boka. "Var det side 33? Skulle vi kunne alle disse? - Nei, bare de femten første på lista." Gloseprøven er i neste time. Jeg er ikke forberedt. Jeg lærer meg de tre første ordene på lista utenat. Så føyer jeg til enda to ord. Jeg gjentar de fem ordene flere ganger. På tysk og på norsk. Det tar noen minutter før de sitter. Jeg skriver dem ned en gang. Det ene ordet ble feil. Jeg føyer til flere ord. Pugger dem. Skriver dem ned. Så ringer det inn. Jeg er litt usikker på et par av ordene. Hva var "severdighet" på tysk igjen? Jeg kikker på lista en gang til i klasserommet. Flere av de andre gjør det samme. Læreren ber oss myndig om å legge bort bøkene. Hun deler ut prøven. Kom igjen! Vær litt rask! Sehenswürdigkeit, Sehenswürdigkeit, Sehenswürdigkeit. "Psst! Janne! Hva var enveiskjøring igjen?" Læreren hysjer og legger prøven foran meg. Jeg skriver raskt ned de ordene jeg var usikker på. Var det to prikker over u-en i det ordet? Var det die eller das? Jeg får et halvt poeng uansett. Jeg tror jeg klarer de fleste. Jeg gjør meg ferdig og leverer prøven. Neste uke er jeg litt flinkere. Jeg pugger ordene kvelden før prøven og kan ta det litt roligere i matfri. Etter tre år med tysk og 10, 15 eller 20 nye ord i uka, burde jeg kunne hundrevis, ja, over tusen ord. Likevel har jeg følelsen av å ikke kunne noen ting.

\subsection{Innledning}

Denne lille historien er ment å illustrere min egen opplevelse av hvordan elever arbeider med ordinnlæring i engelsk og fremmedspråk, og stemmer godt overens med Ulrika Tornbergs beskrivelse i boka Språkdidaktik. I følge Tornberg sier elevene selv at de lærer nye ord på fremmedspråket ved å først dekke over den venstre spalten og teste seg selv, for så å dekke over den høyre spalten og teste seg selv den andre veien. Slik lærer de seg å oversette ordene og eventuelt å stave eller uttale dem, avhengig av om innlæringen er skriftlig eller muntlig (jf. 2015, s. 123-124). Elevene er imidlertid avhengige av at ordene testes i den samme rekkefølgen som de ble lært inn og de lærer ingenting om hvordan ordene brukes i andre sammenhenger enn i en ordliste (jf. Tornberg 2015, s. 123-124). Tornberg påpeker at innkoding av nye ord bare er et steg på veien. Ordene må også lagres og kunne hentes fram igjen. Pugging av ordlister er også langt i fra den eneste metoden for innkoding. Det er heller ikke den beste for alle elever, skriver Tornberg (jf. 2015, s. 132-133). 


\section{Nordic Journal of Modern Language Methodology}

\section{Lareplan i fremmedspråk i LK06 (Læreplanverket for Kunnskapsløftet 2006)}

representerer samme perspektiv. Ordinnlæring ligger under mange av målene i læreplanen som en forutsetning. Eksplisitt nevnes ordinnlæring under hovedområdet kommunikasjon. Nivå I: "Eleven skal kunne forstå og bruke et ordforråd som dekker dagligdagse situasjoner". (Utdanningsdirektoratet 2006). Det står ikke hvordan eleven skal oppnå dette. Læringsstrategier er imidlertid vektlagt i læreplanen og under hovedområdet språklæring står det at læringsutbyttet i faget vil kunne øke ved "å utvikle evnen til å bruke hensiktsmessige læringsstrategier, som å definere egne læringsbehov, formulere mål, velge arbeidsmåter, bruke hjelpemidler og vurdere arbeidsprosess og måloppnåelse individuelt og i samarbeid med andre" (LK06). Det skal altså være en bevissthet rundt hvordan man jobber med de forskjellige kompetansemålene, og dette vil også gjelde for arbeidet med ordforrådet.

I det nevnte læringsmålet legges det vekt på at eleven skal kunne forstå og bruke ordene i en autentisk sammenheng. Man kan, som Tornberg, spørre seg om en ordliste er en slik sammenheng. Pugging av lister med ord er ikke nødvendigvis overførbart til bruk i dagligdagse situasjoner, selv om det kan være et skritt på veien. Vurdering er ikke emnet for denne undersøkelsen. Men det kan tilføyes at en tradisjonell gloseprøve alene ikke vil gi godt nok grunnlag for å vurdere grad av måloppnåelse innenfor dette kompetansemålet.

Gloseprøven tester elevene i å huske ordene, og i å kunne oversette ord mellom målspråk og morsmål. For å vurdere måloppnåelse i forhold til kompetansemålene i læreplanen, kreves et supplement i form av oppgaver som tester forståelse og bruk av ordene.

I Lareplan i fremmedspråk på nivå II er kompetansemålet som nevner ordinnlæring formulert slik: "Eleven skal kunne bruke ord, setningsoppbygning og tekstbindingsformer målrettet og variert" (Utdanningsdirektoratet 2006). Den pragmatiske kunnskapen om ordet vektlegges ytterligere sammenlignet med nivå I. Ord kan ha ulik betydning i ulike kontekster. Når skal man bruke $d u$ og Sie? Hvilke assosiasjoner har ordene Maul og Mund? (jf. Bjørke mfl. 2018, s. 156). Vi ser også at kun produktiv kunnskap er nevnt, og at reseptiv kunnskap er utelatt. Både produktiv kunnskap og pragmatisk kunnskap kjennetegner en dypere forståelse av ord, ifølge Nation \& Laufer. Å vite hvordan ordet skrives og uttales, samt å vite hva det betyr er mer grunnleggende kunnskap (jf. Nation \& Laufer 2012, s. 165).

Ord og ordforråd nevnes altså bare direkte i ett kompetansemål på nivå I og II i Lareplan i fremmedspråk. Dette kan, ifølge Bjørke mfl. (2018), ha sammenheng med at 
språklæringsforskningen ikke har vektlagt dette. Det er imidlertid i endring og forskningen anerkjenner nå hvor viktig ordforrådet er i forbindelse med lesing og for elevenes kommunikative kompetanse, ifølge nyere oversiktsverker i fremmedspråksdidaktikk (jf. Bjørke mfl. 2018, s. 155 og 157-158; Nation \& Laufer 2012, s. 163).

LK06 vektlegger læringsstrategier og hele hovedområdet "Språklæring" i Lareplan $i$ fremmedspråk omhandler dette. Bevisst opplæring i og bruk av læringsstrategier skal være en viktig del av opplæringen i fremmedspråkene. Det følger logisk at dette også må gjelde for ordinnlæring. Dette støtter både Tornberg (2015) og Bjørke mfl. (2018) opp under. Begge understreker betydningen av ordlæringsstrategier i sine oversiktsverker i fremmedspråksdidaktikk. Elevene må lære ordlæringsstrategier fordi ordinnlæring er en kompleks prosess (jf. Bjørke mfl.). De legger også vekt på nytten av å beherske ordlæringsstrategier i møte med målspråket utenom skolen. Ordinnlæringsstrategier er viktige i et livslangt språklæringsperspektiv (Bjørke mfl. 2018, s. 163). Tornberg begrunner fokuset på ordinnlæringsstrategier i tillegg med at elevene lærer på ulike måter. Hun snakker om ulike læringsstiler. Elevene trenger å bli bevisste på hvordan de selv lærer best (jf. Tornberg 2015, s. 132-136). Bjørke mfl. legger også vekt på strategier for å omgå mangel på ord, som kunnskap om transparente ord, morfologi, aktivering av forkunnskaper og en generell ovenfra-ned tilnærming til ny tekst (jf. 2018, s. 138).

Læreplanen og forskningsoversiktene av Bjørke (2018), Tornberg (2015) og Nation \& Laufer (2012) er altså tydelige på at det skal arbeides eksplisitt med ordinnlæring i fremmedspråkundervisningen og at en bevisstgjøring av ordlæringsstrategier skal være en viktig del av dette arbeidet. Det er også enighet om at forståelse og bruk av ordene i autentiske kommunikasjonssituasjoner er målet. Det vil derfor være interessant å se på hvordan det blir jobbet med ordlæringsstrategier i klasserommene i norske skoler.

I artikkelen "Lærarhaldningar til språklæringsstrategiar" undersøker Åsta Haukås 145 norske fremmedspråklæreres holdninger til og fokus på læringsstrategier i undervisningen. Artikkelen er basert på en spørreunders $\emptyset$ kelse. Resultatene viser at flertallet har en positiv innstilling til læringsstrategier og at mange lærere snakker en del til elevene om temaet. Det er imidlertid lite arbeid med læringsstrategier i klasserommet. I artikkelen definerer hun språklæringsstrategier som "bevisste tankar eller framgangsmåtar eleven nyttar for å støtte hans eller hennar språklæringsprosess" (Haukås 2012). Det er altså ikke nok at læreren 


\section{Nordic Journal of Modern Language Methodology}

foreleser om emnet. Han eller hun bør legge til rette for at eleven får jobbe aktivt med språklæringsstrategiene.

Flertallet av norske lærere sier at de kan for lite om læringsstrategier og etterlyser kurs og videreutdanningstilbud (jf. Haukås 2012, s. 116). Et annet perspektiv, som denne undersøkelsen tar for seg, er læreboka. Læreboka er et viktig arbeidsredskap for læreren. Den letter arbeidet med både kortsiktig og langsiktig planlegging. Det fritar selvsagt ikke læreren fra selv å tolke læreplanen og legge opp undervisningen deretter, men en god lærebok kan være en støtte i dette arbeidet. I læreboka i fremmedspråk kan man finne tilrettelagte tekster og forslag til aktiviteter. Man finner gjerne en oversikt over grammatiske emner med oppgaver til. Bøkene inneholder gjerne også gloser og utvalgte ordinnlæringsøvelser. Men hvor systematisk er dette lagt opp? I hvilken grad kan lærebøkene lette lærerens arbeid med ordinnlæringsstrategier?

\section{Problemstilling}

Basert på det ovenstående har jeg valgt følgende todelte problemstilling:

1. Hvilke typer ordinnlæringsøvelser finnes i to mye brukte lærebøker i tysk som fremmedspråk på nivå 1 på videregående skole?

2. Inneholder lærebøkene oppgaver for arbeid med metakognitive ordinnlæringsstrategier?

\section{Metode}

For å undersøke denne problemstillingen har jeg tenkt å ta for meg to læreverk i tysk som fremmedspråk: Weitblick fra Aschehoug (Nygård mfl. 2013) og Anflug 1 (Arbeitsbuch og Textbuch) fra Cappelen (Andersen \& Bali 2006a og 2006b). Begge er skrevet til bruk i norsk videregående skole på nivå 1 . Dette gjør det mulig å sammenligne dem. Nivå II er utelatt for å begrense fokus.

Undersøkelsen analyserer ordinnlæringsøvelser i lærebøkene i lys av hvilke læringsstrategier de representerer. For å besvare spørsmålene i problemstillingen bruker undersøkelsen Morfelds (1998) inndeling, slik den blir benyttet i en bearbeidet versjon av Gausland 


\section{Nordic Journal of Modern Language Methodology}

og Haukås (2011). De baserer seg på en inndeling i kognitive og metakognitive ordinnlæringsstrategier med underinndelinger. Inndelingen gir en grov oversikt over tendenser i bøkene. Deretter vil undersøkelsen analysere konkrete eksempler i lærebøkene.

Undersøkelsen ser også på hvorvidt ordinnlæringsøvelsene understøtter de tre delprosessene i ordinnlæring: forståelsesprosessen, lagringsprosessen og gjenfinningsprosessen (jf. Bjørke mfl. 2018; Tornberg 2014). Et annet viktig spørsmål i denne undersøkelsen er om læreboka legger opp til bevisst arbeid med ordinnlæringsstrategier. Hvor utstrakt er bruken av metakognitive ordinnlæringsstrategier? Her er det heller ikke snakk om å tallfeste dette eksakt, men om å få øye på og analysere tendenser.

\subsection{Klassifisering av ordinnlæringsstrategier}

Det er flere mulige måter å klassifisere språklæringsstrategier generelt og ordinnlæringsstrategier spesielt på. En mye brukt klassifisering baserer seg på Rebecca Oxfords bok Language Learning Strategies: What Every Teacher Should Know (1990). Det er også blitt utviklet en spørreundersøkelse basert på denne klassifiseringen: Strategy Inventory for Language Learning (SILL). Den regnes som utdatert, men fremdeles nyttig (jf. Bjørke mfl. 2018; Haukås 2012). Det er imidlertid flere kategorier hos Oxford som faller utenfor rammene for denne unders $\varnothing$ kelsen, for eksempel kompensasjonsstrategier, sosiale strategier og affektive strategier. Haukås påpeker også et uklart skille mellom kognitive strategier og minnestrategier (jf. Bjørke mfl. 2018, s. 69).

Tornberg støtter seg på Howard Gardners teori om læringsstiler (jf. Tornberg 2015, Gardner 1993). Hun presenterer fem "intelligenser" som tilsvarer fem metoder som elevene kan prøve ut når de skal lære nye ord:

1. Lingvistisk/språklig intelligens

2. logisk-matematisk intelligens

3. visuell-spatial intelligens

4. musikalsk intelligens

5. kroppslig-kinestetisk intelligens 


\section{Nordic Journal of Modern Language Methodology}

Hun er også opptatt av at elevene må arbeide bevisst med ordinnlæringsstrategier og deler derfor implisitt opp i kognitive og metakognitive strategier.

Denne undersøkelsen bruker Morfelds (1998) inndeling, slik den finnes i en bearbeidet versjon hos Gausland og Haukås (2011). Denne inndelingen gjør det mulig å se på noen tendenser til hvilke oppgavetyper og ordinnlæringsstrategier som blir vektlagt i lærebøkene. Klassifiseringen ser slik ut:

\section{Kognitive strategier}
a. Repetisjon og memorering
b. Kontekstualisering
c. Kontrastering og differensiering
d. Visualisering og assosiering
e. Strukturering

2. Metakognitive strategier
a. Organisere og planlegge
b. Evaluere læringsutbytte og læringsmetoder

Repetisjon og memorering kan være at man gjentar ordene høyt eller i hodet, at man skriver ordene gjentatte ganger, eller at man går igjennom en liste med ord flere ganger, mens man dekker over kolonnen med tyske eller norske ord. Med kontekstualisering menes фvelser hvor man bruker ordene i en sammenheng, for eksempel en setning eller en parallelltekst. Kontrastering skjer i forhold til morsmålet eller andre fremmedspråk, men differensiering skjer innen målspråket. I visualisering og assosiering bruker man mentale eller reelle bilder, som for eksempel i keyword-metoden, eller man gir ordene assosiasjoner ved hjelp av rim, rytme eller tall. Strukturering innebærer en eller annen form for ordning av ordene, for eksempel etter ordklasse, betydning eller egne kategorier (Gausland og Haukås 2011, s.4).

De metakognitive strategiene tilsvarer det som står i læreplanen under hovedområdet språklæring, især kompetansemålet "eleven skal kunne beskrive og vurdere eget arbeid med å lære det nye språket" (Utdanningsdirektoratet 2006). Oppdelingen i kognitive og metakognitive strategier, og den videre inndelingen av kognitive strategier, gir sammen et godt utgangspunkt for å svare på problemstillingen. 


\section{Nordic Journal of Modern Language Methodology}

Norbert Schmitt gir en oversikt over fors $\emptyset \mathrm{k}$ på å kategorisere ordinnlæringsstrategier i artikkelen "Vocabulary learning strategies". Han peker på vanskeligheten med å skille skarpt mellom ordinnlæringsstrategier og mer generelle språklæringsstrategier, siden en strategi kan bli brukt med forskjellige mål for øye. Det er også vanskelig å trekke en klar grense mellom de forskjellige ordinnlæringsstrategiene (jf. Schmitt 1997, s. 199-204). Kategoriseringen som blir foretatt i denne undersøkelsen må derfor ses på som en hjelp til å organisere og få oversikt over materialet for å se på variasjon. Kategoriseringen vil kunne si noe om tendenser $\mathrm{i}$ bøkene. Deretter vil det være nødvendig å studere konkrete eksempler for å kunne svare på spørsmålene i problemstillingen.

\subsection{De tre delprosessene}

Noen av de nevnte kognitive strategiene støtter først og fremst innkodingen av nye ord. De er såkalte overflatestrategier. Repetisjon og memorering er et eksempel på en slik overflatestrategi. Dette er bare et første steg på veien mot forståelse og bruk av ordene i en kommunikasjonssituasjon. Ordene må tas aktivt i bruk i nye, meningsfulle sammenhenger. Dette skaper assosiasjonsnettverk som gjør ordene tilgjengelige ved senere anledninger. Det er nødvendig med ordinnlæringsøvelser som støtter både forståelsesprosessen, lagringsprosessen og gjenfinningsprosessen (jf. Bjørke mfl. 2018, s. 162; Golden 2014). Aktiviteter som innebærer for eksempel kontekstualisering og assosiering fører til den nødvendige kognitive bearbeidelsen (jf. Bjørke mfl. 2018, s. 162-165). Det er imidlertid en gradsforskjell i denne kategorien av strategier. Tornberg (2012) foreslår ulike øvelser som skal hjelpe elevene til forståelse og bruk av ordene i nye sammenhenger:

- Ordene kan brukes til å gjenfortelle, sammenfatte eller dramatisere en tekst

- Ordene kan brukes til å diskutere en tekst

- Ordene kan brukes i en helt ny dialog eller en helt ny tekst

- Ordene kan brukes i en muntlig framføring

- Ordenes personlige konnotasjoner kan diskuteres blant elevene

Her er det ikke lenger bare snakk om ordinnlæring, men også om det Tornberg kaller "en mångdimensionell språklig gestaltning" (Tornberg 2012, s. 137). 


\section{Nordic Journal of Modern Language Methodology}

2019, 7 (1), 84-115 (Part B - Not peer reviewed)

\subsection{Inneholder lærebøkene oppgaver for arbeid med metakognitive ordinnlæringsstrategier?}

For å svare på dette spørsmålet tar undersøkelsen utgangspunkt i de metakognitive strategiene: legger aktivitetene som er beskrevet i læreboka opp til at elevene skal organisere og planlegge ordinnlæringen og evaluere læringsutbytte og læringsmetoder? De metakognitive strategiene er i en særstilling i og med at de ideelt sett skal utgjøre rammen som all språklæringen og ordinnlæringen skal foregå innenfor, slik at elevene skal kunne dra nytte av disse strategiene i et livslangt språklæringsperspektiv.

\section{Beskrivelse av lærebøkene}

\subsection{Læreverket Anflug 1}

Læreverket Anflug 1 består av en tekstbok og en arbeidsbok. I forordet til tekstboka beskrives det overordnede målet med læreverket. Elevene skal bruke tysk aktivt ved å snakke, lytte, lese og skrive i ulike situasjoner. I tillegg skal de få innsikt i levemåte og kultur i de tyskspråklige landene gjennom tekster i ulike sjangre (Andersen og Bali 2006a, s. 5-6). Dette er i overenstemmelse med læreplanen. Ordforråd og ordinnlæring blir nevnt i tre sammenhenger i forordet. Hvert kapittel i tekstboka inneholder tekst med glossar i marg og praktisk tysk, det vil si ord og uttrykk som kan brukes i autentiske kommunikative situasjoner. Hvert kapittel i arbeidsboka inneholder oppgaver til glossaret (Andersen \& Bali 2006a, s.5-6).

\section{Glossar og praktisk tysk i Anflug 1. Textbuch}

I tillegg til det som blir nevnt i forordet til boka, møter vi også noen eksplisitte ordlæringsoppgaver i "Vor dem Lesen" og "Aufgaben zum Text".

\section{Vor dem Lesen}

13 av 15 kapitler i Anflug 1. Textbuch begynner med en førleseoppgave under overskriften "Vor dem Lesen". 8 av disse oppgavene er arbeid med gloser og kan betegnes som ordinnlæringsoppgaver. Kapitlene som innledes med slike $\emptyset$ velser er kapittel 1, 2, 3, 4, 6, 7, 9 og 12. Når det gjelder førleseoppgavene er det altså flere ordinnlæringsøvelser i begynnelsen 


\section{Nordic Journal of Modern Language Methodology}

av boka enn i slutten. Det kan være tilfeldig eller det kan være en del av et bevisst fokus på ordinnlæring tidlig i opplæringen.

Oppgavene er varierte. Førlesingsoppgaven i kapittel 1 handler om transparente verb, som kommen (komme), reisen (reise), hören (høre), osv. Ordene er lette å kjenne igjen for en elev som kan norsk. Eleven skal se på ordene og forsøke å oversette dem til norsk (Andersen \& Bali 2006a). Det kan være nyttig å fokusere på transparente ord tidlig i fremmedspråkopplæringen: "[Cognates] are easy to learn and introducing them in large numbers can enrich learners functioning in a foreigne language and concequently positively affect their confidence and motivation (Nation \& Laufer 2012, s.164).

I førlesingsoppgaven til kapittel 4 skal elevene lage en tematisk liste over familiemedlemmer i tillegg til at de skal kombinere ord og bilde. I kapittel 9 om temaet sport skal elevene kategorisere idretter på to forskjellige måter. I førlesingsoppgaven til kapittel 12 skal elevene arbeide med assosiasjoner (Andersen \& Bali 2006a).

Det er altså variasjon i type oppgaver. Felles for disse ordinnlæringsøvelsene er at ordene til en viss grad blir tatt opp igjen i teksten, i oppgavene etter teksten og i delen som heter praktisk tysk.

\section{Glossar}

Tekstene i Anflug 1. Textbuch har gloser i margen. Dette gjør dem lett tilgjengelig under lesingen. Det forekommer både ord som hører til et bestemt tema og ord som kan være nyttige i flere sammenhenger. I kapittel 11 er det for eksempel 26 gloser som hører til temaet (mat og helse), mens det er 14 andre ord (trotzdem, tun, weniger als, das Rad, osv.). De fleste ordene virker nyttige å kunne, men trotzdem (s. 99) er kanskje viktigere enn das Gleitschirmfliegen (s. 82), siden det kan brukes i flere sammenhenger. Substantiv blir oppgitt med bestemt artikkel og flertallsendelse bak bindestrek (Getränk das, -e). Verb står i infinitiv.

Det er ingen $\varnothing$ velser knyttet direkte til glosene men flere av glosene som hører til kapittelets tema dukker opp igjen i "Aufgaben zum Text" og praktisk tysk. I kapittel 11 gjelder dette 8 av 40 ord. I tillegg legger oppgavene opp til at flere ord skal tas i bruk.

\section{Aufgaben zum Text}




\section{Nordic Journal of Modern Language Methodology}

I "Aufgaben zum Text" finnes flere typer oppgaver som direkte eller indirekte har med ordinnlæring å gjøre: skrive parallelltekst (s. 23 og 134), gjenfortelle tekst (s. 63), forklare et ord uten å bruke ordet, skrive parallelldikt, luketekst (alle på s. 84), skrive stikkord og fortelle (s. 103 og 110), bruke uttrykk fra praktisk tysk (s. 110 og 118), si ordet i en setning (s. 134).

\section{Praktisk tysk}

På slutten av hvert kapittel står seksjonen "Praktisk tysk". Seksjonen presenterer eleven for forskjellige nyttige uttrykk eller chunks. Første kapittel handler om å prentere seg og bli kjent. Eksempel på uttrykk er Woher kommst du? og Ich komme aus Norwegen (s. 17). I kapittel 9 har det blitt litt mer avansert. Kapitlet inneholder for eksempel preposisjonsfraser, spørsmål om pris, begrunnelser og små dialoger om å gjøre avtaler og spørre om tiden. Disse seksjonene inneholder mange nyttige og viktige uttrykk. Noen få oppgaver er direkte knyttet til disse uttrykkene. Ellers er man henvist til formuleringen i forordet: "Praktisk tysk (ord og uttrykk som kan brukes i kommunikative situasjoner)" (s. 5). Det er altså ingen tvil om hva som er hensikten med "Praktisk tysk", men det er få konkrete tips til hvordan det skal gjennomføres.

\section{Oppgaver til glossaret i Anflug 1. Arbeitsbuch}

Det finnes mange ordinnlæringsoppgaver i tekstboka. Det er imidlertid i arbeidsboka det er flest av dem. Anflug 1. Arbeitsbuch inneholder hundrevis av ordlæringsoppgaver.

\subsection{Weitblick 1}

I læreverket Weitblick 1 er alt av tekster, oppgaver og grammatikk samlet i et bind. Læreboka inneholder ikke noe forord, men det står en beskrivelse på baksiden av boka:

Læreboken Weitblick 1 har et bredt utvalg av både autentiske og tilrettelagte tekster for elever på nivå 1. Dette er en kombinert lese- og arbeidsbok med integrert minigrammatikk, liste over sterke verb og gloser. Boken er rikt illustrert med bilder som støtter leseforståelsen. Til alle tekstene finnes det varierte arbeidsoppgaver og grammatikkoppgaver (Nygård m.fl. 2013). 


\section{Nordic Journal of Modern Language Methodology}

2019, 7 (1), 84-115 (Part B - Not peer reviewed)

Det er ikke beskrevet noe overordnet mål for læreverket i motsetning til i Anflug 1, men førsteinntrykket er at mye av det samme er med, bare litt mer komprimert.

\section{Gloser}

Weitblick 1 inneholder gloser i margen, lett tilgjengelig under lesingen. Substantiv er oppgitt med artikkel og flertallsform. Sterke og uregelrette verb er oppgitt med informasjon om hvordan de bøyes. Verbene er ellers av og til oppgitt i infinitiv, andre ganger i den formen de står i teksten. Boka har i tillegg en alfabetisk gloseliste bak (Nygård m.fl. 2013, s. 287-299).

\section{Wörter und Wendungen}

Slik som i Anflug 1 har Weitblick 1 en seksjon med nyttige ord og uttrykk etter tekstene og før oppgavene i noen av kapitlene. I Weitblick 1 heter denne seksjonen "Wörter und Wendungen". Kapittel 4 inneholder for eksempel en oversikt over tidsuttrykk (Nygård mfl. 2013, s. 69), mens kapittel 7 har ord og utsagn knyttet til kapitteltemaet "Auf dem Land" (s. 123). Strukturen er imidlertid litt løsere enn i Anblick 1. I noen kapitler er det ingen slik seksjon, for eksempel i kapittel 8 og 11, mens kapittel 7 har en seksjon med en dialog og en oversikt over vintersportsgrener på slutten. Kapittel 10 har fakta om Luxembourg (s. 173). I likhet med i Anblick 1 er det ikke oppgitt hvordan man skal jobbe med disse ordene og uttrykkene, bortsett fra der det blir henvist til dem i oppgavedelen.

\section{Aufgaben og Grammatik}

Hvert kapittel har en oppgavedel under overskriftene "Aufgaben" og "Grammatik".

Oppgavene under "Aufgaben" har underoverskriftene "Lese og forstå", "Snakke", "Skrive", "Lytte, lese og forstå" eller en kombinasjon av disse. Ordinnlæring blir ikke nevnt i overskriften til oppgavene. Oppgavene under "Grammatik" er naturlig nok grammatikkoppgaver. Selv om det i overskriftene blir lagt vekt på andre sider av språklæringen enn ordinnlæring, er mange av oppgavene relevante for denne unders $\varnothing$ kelsen (se avsnitt 5.1). Her er ved første øyekast også stor variasjon i type oppgaver, slik det var i Anflug 1. Elevene skal for eksempel lage både muntlige og skriftlige parallelltekster, de skal ordne ord i forskjellige kategorier og de skal bli bevisste på de mange transparente ordene i tysk, når man kan norsk og engelsk fra før. 


\section{Kategorisering av ordinnlæringsoppgaver og analyse}

\subsection{Oppgaver undersøkelsen skal fokusere på}

Tabellen under skal gi en oversikt over hvilke oppgaver som er med i hver kategori.

Unders $\varnothing$ kelsen foretar en opptelling og kategorisering av ordinnlæringsøvelser for å skaffe seg en oversikt over tendenser i lærebøkene. Så vil enkeltøvelser bli analysert mer inngående.

Diskusjon av hvilke oppgaver undersøkelsen skal fokusere på kommer under tabellen.

\begin{tabular}{|l|l|l|}
\hline Oppgavetype & Ja/Kategori & Nei \\
\hline Bruk av ordbok & Organisere og planlegge (?) & \\
\hline Definisjon & Kontekstualisering & \\
\hline $\begin{array}{l}\text { Gjentakelse av uttrykk } \\
\text { (klokkeslett, tidsuttrykk, } \\
\text { osv.) }\end{array}$ & Repetisjon og memorering & \\
\hline $\begin{array}{l}\text { Gjette betydningen til ord ut } \\
\text { i fra kontekst }\end{array}$ & Kontekstualisering & \\
\hline $\begin{array}{l}\text { Grammatikk - sett inn riktig } \\
\text { ord (adjektiv, eiendomsord, } \\
\text { preposisjon, pronomen, } \\
\text { verb, osv.) / ord som gir } \\
\text { mening i konteksten }\end{array}$ & Kontekstualisering & \\
\hline $\begin{array}{l}\text { Grammatikk - verbbøyning, } \\
\text { adjektivbøyning, kasus - } \\
\text { fokus på morfologi eller } \\
\text { setningsstruktur }\end{array}$ & Kontekstualisering & \\
\hline $\begin{array}{l}\text { Kobling ord og bilde } \\
\text { gloseliste til et tema, osv. }\end{array}$ & Strukturering & \\
\hline $\begin{array}{l}\text { Ordning av ord i grupper, } \\
\text { Visualisering og assosiering }\end{array}$ & \\
\hline
\end{tabular}




\section{Nordic Journal of Modern Language Methodology}

2019, 7 (1), 84-115 (Part B - Not peer reviewed)

\begin{tabular}{|c|c|}
\hline Ordsalat & Kontrastering og differensiering \\
\hline Ortografi & Kontrastering og differensiering \\
\hline Parallelldikt & Kontekstualisering \\
\hline Rim, rytme, regler & Visualisering og assosiering \\
\hline $\begin{array}{l}\text { Spørreunders } \emptyset \text { kelse om } \\
\text { læringsstiler - hvordan lærer } \\
\text { jeg best? }\end{array}$ & $\begin{array}{l}\text { Evaluere læringsutbytte og læringsmetoder, } \\
\text { organisere og planlegge (obs! generelt for } \\
\text { språklæring) }\end{array}$ \\
\hline Stikkord -> gjenfortelling & Kontekstualisering \\
\hline Tankekart, assosiogram & Strukturering \\
\hline Transparente ord & Kontrastering og differensiering \\
\hline Uttale & Kontrastering og differensiering \\
\hline Uttale - repetisjons $\emptyset$ velse & Repetisjon og memorering \\
\hline
\end{tabular}

\section{Hva er en ordinnlæringsøvelse?}

Unders $\emptyset$ kelsen foretar to viktige avgrensninger i kategoriseringen av oppgaver fra bøkene. Den første avgrensningen baserer seg på inndelingen av ord i ordklasser og inndelingen av ord i funksjonsord og innholdsord. Den andre avgrensningen er representert i tabellen ovenfor og gjelder hvilke typer oppgaver undersøkelsen definerer som ordinnlæringsøvelser. Når det gjelder den første avgrensningen, er alle ordklasser med i undersøkelsen. Når det gjelder den andre avgrensningen er noen oppgaver som i hovedsak er grammatikkoppgaver ikke med.

\section{Inndeling av ord}

Ord kan deles inn på forskjellige måter. Anne Golden presenterer i Ordforråd, ordbruk og ordlaering (2014) to måter som er relevante for denne undersøkelsen: inndeling i ordklasser og inndeling i funksjonsord og innholdsord. Golden skiller mellom åpne og lukkede ordklasser. Det kommer stadig nye substantiver, verb og til en viss grad adjektiver inn i språk som norsk og tysk, mens andre ordklasser er relativt stabile (jf. Golden 2014, s. 39). Denne undersøkelsen tar for seg både åpne og lukkede ordklasser, fordi også ordene i lukkede ordklasser må læres og eventuelle strategier for å lære disse er relevante for problemstillingen.

Det samme argumentet vil gjelde for skillet mellom innholdsord og funksjonsord. Dette skillet overlapper med skillet mellom åpne og lukkede ordklasser, men som begrepene 


\section{Nordic Journal of Modern Language Methodology}

2019, 7 (1), 84-115 (Part B - Not peer reviewed)

sier handler det her om hvor mye innhold ordene har. Funksjonsord viser til forholdet mellom innholdsordene i et utsagn og blir derfor også kalt grammatiske ord (jf. Golden 2018, s. 42). I lærebøkene vil oppgaver som handler om å lære inn disse, ofte falle inn under grammatikkdelen av boka. Det vil likevel være interessant å se om boka presenterer noen strategier for å lære disse. Presenterer for eksempel læreboka elevene for en regle som kan hjelpe dem å lære vekselpreposisjonene?

\section{Grammatikkoppgaver}

Av diskusjonen ovenfor følger at en del oppgaver som også er grammatikkoppgaver være en del av undersøkelsen. Men skal alle grammatikkoppgaver være med? Hører det ikke med til kunnskapen om subjunksjoner at de innleder leddsetninger og at verbet da kommer til slutt? Hører det ikke med til kunnskapen om verb at man kan bøye dem? Og er det ikke viktig å vite hvilken kasus de forskjellige preposisjonene styrer? Svaret på alle tre spørsmålene er ja. Hos Anne Golden blir det å kjenne til hvilke bøynings- eller avledningsformer et ord forekommer i, regnet som formal ordkunnskap. Under formal kunnskap faller i tillegg ortografi og uttale (jf. 5.1.2.3). Det å vite at subjunksjoner innleder leddsetninger, er syntaktisk kunnskap. Hun deler videre opp kunnskapen om ord i semantisk og pragmatisk kunnskap (jf. Golden 2014, s. 70).

Disse oppgavene er likevel ikke tatt med i denne undersøkelsen. Skillet mellom ordinnlæring og grammatikk er flytende, akkurat som skillet mellom ordinnlæring og skriving, ordinnlæring og lesing, og ordinnlæring og lytting er flytende. Når man arbeider med å lære et nytt språk er det ikke vanntette skott mellom de forskjellige elementene man skal lære, men det kan være nyttig å operere med kategorier blant annet for å kunne fokusere på det man ønsker å bli bedre til. Her er avgrensningen altså til en viss grad basert på intuisjon. Når man arbeider med verbbøying, adjektivbøying, kasus og ordstilling, er fokuset i større grad på grammatikk enn på ordinnlæring. Det er også slik at oppgavene som er knyttet til disse elementene ikke tilfører noe vesentlig nytt til analysen som unders $\varnothing$ kelsen foretar.

Det kommer kanskje ikke som en overraskelse at disse oppgavene i stor grad er utfyllingsoppgaver (se diskusjon under). Formal og syntaktisk kunnskap om ordet vil imidlertid være en viktig del av mange andre oppgaver i bøkene, for eksempel de som går på 


\section{Nordic Journal of Modern Language Methodology}

bruk av ord i samtaler og tekstskriving. I følge Golden glir de ulike kunnskapene over i hverandre (2014, s. 71).

\section{Ortografi og uttale}

En type formal ordkunnskap som er tatt med i undersøkelsen er ortografi og uttale. Dette er for det første grunnleggende kunnskap om ord. I tillegg tar disse $\emptyset$ velsene ofte i bruk strategier som ikke er så godt representert andre steder. Igjen kunne grensen ha vært trukket et annet sted, men her med større konsekvenser for resultatet av undersøkelsen.

\subsection{Tabeller}

Undersøkelsen bruker en kategorisering basert på Gausland og Haukås (2011). Oppgavene i boka har blitt talt opp og plassert i kategorier jamfør diskusjonen ovenfor. Tabellene skal som sagt bare gi en oversikt over tendenser i lærebøkene. En mer inngående lesning og diskusjon av oppgavene i lærebøkene følger etter tabellene.

\section{Inndeling av ordinnlæringsøvelser i Anflug 1. Textbuch og Arbeitsbuch}

\begin{tabular}{|l|l|l|l|}
\hline Strategi & \multicolumn{2}{l|}{ Ordlæringsøvelser } \\
\hline & Textbuch & Arbeitsbuch & Totalt \\
\hline Kognitive strategier & & & \\
\hline Repetisjon og memorering & 0 & 23 & 23 \\
\hline Kontekstualisering & 10 & 95 & 105 \\
\hline Kontrastering og differensiering & 2 & 68 & 70 \\
\hline Visualisering og assosiering & 2 & 15 & 17 \\
\hline Strukturering & 6 & 19 & 25 \\
\hline Metakognitive strategier & & & \\
\hline Organisere og planlegge & 0 & 4 & 4 \\
\hline $\begin{array}{l}\text { Evaluere læringsutbytte og } \\
\text { læringsmetoder }\end{array}$ & 0 & 1 & 1 \\
\hline Antall $\varnothing$ velser totalt & 20 & 225 & 245 \\
\hline
\end{tabular}


Inndeling av ordinnlæringsøvelser i Weitblick 1

\begin{tabular}{|l|l|}
\hline Strategi & Ordlæringsøvelser \\
\hline Kognitive strategier & Antall \\
\hline Repetisjon og memorering & 11 \\
\hline Kontekstualisering & 101 \\
\hline Kontrastering og differensiering & 55 \\
\hline Visualisering og assosiering & 7 \\
\hline Strukturering & 26 \\
\hline Metakognitive strategier & 1 \\
\hline Organisere og planlegge & \\
\hline $\begin{array}{l}\text { Evaluere læringsutbytte og } \\
\text { læringsmetoder }\end{array}$ & 201 \\
\hline Antall $\emptyset$ velser totalt & \\
\hline
\end{tabular}

\subsection{Analyse}

\section{Oversikt og tendenser}

De to læreverkene presenteres sammen siden resultatene er relativt like for begge.

Diskusjonen vil derfor være organisert etter inndelingen av ordinnlæringsøvelser og likheter og forskjeller mellom læreverkene vil bli nevnt under hvert punkt. De kognitive strategiene dominerer i begge læreverkene. Det er også visse underkategorier av de kognitive strategiene som utgjør en stor andel av det samlede antallet. Kategorien kontekstualisering skiller seg ut med en stor andel av oppgavene, mens kontrastering og differensiering er den nest største kategorien. Hadde flere av grammatikkoppgavene vært med i tellingen, hadde disse to kategoriene dominert i enda større grad. Det er også en del struktureringsoppgaver i begge lærebøkene. Begge lærebøkene inneholder også oppgaver i kategoriene repetisjon og memorering og visualisering og assosiering.

Ut i fra disse tendensene kan man tenke seg at bøkene inneholder stor variasjon i type oppgaver, men det kan vi ikke konkludere med før vi har sett nøyere på hvilke oppgaver som ligger i hver kategori. Tabellen sier ikke noe om kvaliteten på oppgavene. Det er derfor 


\section{Nordic Journal of Modern Language Methodology}

2019, 7 (1), 84-115 (Part B - Not peer reviewed)

nødvendig å se nærmere på hver kategori for seg med dette for øye. Analysen tar også for seg mangelen på oppgaver som innebærer bruk av metakognitive strategier.

\section{Kognitive strategier}

\section{Repetisjon og memorering}

Begge lærebøkene inneholder relativt få ordinnlæringsoppgaver i kategorien repetisjon og memorering. Dette står tilsynelatende i kontrast til elevenes selvrapportering i Gausland og Haukås undersøkelse. Men inndelingen av ordinnlæringsoppgaver gir ikke et fullstendig bilde av hvilken status repetisjon og memorering har i lærebøkene. Både bruken av gloselister og enkelte formuleringer i bøkene peker i en annen retning. Neste avsnitt beskriver en type repetisjonsøvelser fra Anflug 1, før noen formuleringer angående repetisjon, spesielt i Weitblick 1, drøftes nærmere.

En oppgavetype som er typisk for Anflug 1 er repetisjon av uttale. En oppgave går for eksempel ut på å lære seg de forskjellige s-lydene i tysk. Det er eksempel på ord med [s] i midten av ordet, [s] i slutten av ordet, og [J] i begynnelsen og i slutten av ord. Det er tegning av høretelefoner ved siden av oppgaven, noe som betyr at man skal benytte seg av lydfilene som hører til boka. Instruksjonen er å lytte nøye og gjenta i pausene. Ordene kan elevene lese i boka mens de lytter og gjentar (jf. Andersen \& Bali 2006b, Aufgabe 2 a). Her er fokuset ikke på å lære seg enkeltord, men å lære seg uttaleregler som er overførbare til andre ord. Oppgaven er også en praktisk øvelse i å uttale ordene. I begynneropplæringen er dette en viktig del av ordinnlæringen.

Weitblick 1 inneholder mange utsagn om repetisjon hvor det ikke er spesifisert hvordan elevene skal gå fram. Oppgave 1.5 (s. 16): "Øv inn tallene"; 2.2 (s. 34): "Øv inn glosene sammen to og to"; 2.3 (s. 34): "Lær viktige uttrykk som ja, bitte og nein, danke utenat"; 2.34 (s. 40): "Her er det viktig å repetere eiendomsordene før du setter i gang"; 3.17 (s. 54): "Når dere har lært dere viktige ord [...]"; 4.1 (s. 70): "Studer glosene i margen [...]"; 4.13 (s. 71): "Lær viktige gloser"; 4.14 (s. 71): "Lær hvordan man sier de ulike klokkeslettene på tysk"; 5.2 (s. 86): "Repeter spørreordene [...]"; 7.5 (s. 124-125): "[...] studer gloselisten [...]"; 9.8 (s. 157): "Finn dem i teksten, oversett dem til norsk og lær dem." 


\section{Nordic Journal of Modern Language Methodology}

I Anflug 1 finnes det bare ett tilsvarende utsagn: Aufgabe 5c (s. 98): "Lær deg tydinga av preposisjonane". Boka inneholder også andre utsagn som handler om repetisjon, men der er det vist til konkrete steder i boka som eleven skal lese på nytt (jf. Andersen og Bali 2006b).

I disse utsagnene er det forutsatt at elevene vet hvordan de skal lære, lære utenat, øve inn, repetere og studere. Det blir ikke gitt noen nærmere instrukser. Slike oppgaver vil sannsynligvis bli tolket i retning av repetisjon og pugging, også der ordet repetisjon ikke er brukt. Undersøkelsen til Gausland og Haukås tyder på at dette der den strategien som flest elever griper til når ingen nærmere instrukser blir gitt (jf. Gausland og Haukås 2011). En undersøkelse gjennomført med japanske andrespråksbrukere av engelsk kom til samme resultat (jf. Schmitt 1997, s. 219-225). Schmitt gjennomgår også tidligere forskning på feltet og konkluderer med at mer mekaniske strategier blir foretrukket framfor mer komplekse strategier (jf. Schmitt 1997, s. 201 og 215).

Det er også interessant å se nærmere på oppgave 4.1 i Weitblick 1:

\section{Lytte og forstå}

Sitt sammen to og to. Lytt til diktet et par ganger. Hvor mye forstod dere? Hva er temaet i diktet? Studer glosene i margen, les og oversett deretter diktet for hverandre. Hvordan forstår dere den siste strofen i diktet? (Nygård mfl. 2013, s. 70)

For det første er dette et eksempel på at det ikke er mulig å sortere alle oppgavene i bestemte kategorier. Denne oppgaven inneholder både et element av kontekstualisering, i og med at ordene her studeres i forbindelse med en lytte- og lesetekst, og et element av repetisjon, siden man møter ordene både ved å lytte (to ganger), studere glosene, lese, oversette og reflektere over innhold. For det andre er denne oppgaven interessant fordi det er den eneste oppgaven som nevner glosene i margen eksplisitt. Hva betyr det at elevene skal studere glosene i margen? Skal det gjøres adskilt fra neste ledd, som er å lese og oversette diktet for hverandre? La oss si at elevene oppfatter det å studere glosene i margen som et selvstendig trinn $\mathrm{i}$ oppgaven. Hvilken strategi vil elevene gripe til? Og hva sier formuleringen om glosenes funksjon i boka generelt? Elevene skal bruke glosene i margen til å slå opp i når de leser tekstene i boka, slik sett oppfordres det til intensiv lesing av tekster - elevene skal ha forstått hvert ord når de er ferdig med teksten. Det er også forutsatt at elevene vet hva som er ment 


\section{Nordic Journal of Modern Language Methodology}

med å studere glosene. Igjen vil det være nærliggende å gripe til en strategi som inneholder en eller annen form for repetisjon. Det at det finnes bare en slik formulering i Weitblick 1, kan tolkes dithen at det nesten sier seg selv hvordan man skal jobbe med glosene i margen. En annen mulig tolkning er å henvise til lærerens metodefrihet. Læreren står fritt til å velge strategier for ordinnlæring. Det som kan sies sikkert er at ordinnlæring i denne oppgaven er nevnt så å si i en parentes og med en så uklar instruks at det er nærliggende for elevene å enten hoppe over den eller å gripe til mekanisk repetisjon og memorering.

\section{Kontekstualisering}

Både Anflug 1 og Weitblick 1 inneholder mange kontekstualiseringsoppgaver. Men det er ikke alle kontekstualiseringsoppgaver som er like gode. Det er også forskjell på hvor stort fokuset er på ordinnlæring i oppgaveteksten. I denne undersøkelsen er det også relevant å se på om kontekstualiseringsoppgavene blir presentert eksplisitt som strategier for å lære ord.

Mange av kontekstualiseringsoppgavene i de to lærebøkene er lukeutfyllingsoppgaver. Haukås mfl. har foretatt en undersøkelse av lærebøker i tysk som fremmedspråk med fokus på grammatikkoppgaver. De fant en stor overvekt av lukeutfyllingsoppgaver. De hevder at denne typen oppgaver ikke er spesielt effektive for læring av grammatiske former og regler, siden de ikke stimulerer til mye annet enn mekanisk utfylling (jf. Haukås mfl. 2016). Som nevnt ovenfor utelater denne unders $ø$ kelsen en del grammatikkoppgaver, nettopp fordi de i hovedsak representerer denne typen lukeutfyllingsoppgaver, hvor eleven skal finne riktig form av ordet i en tabell og fylle det inn.

Her er eksempler på oppgaver fra lærebøkene som er tatt med i undersøkelsen:

\subsection{Skrive}

Fullfør setningene under. Bruk disse ordene:

Südtirol - Unterkunft - Flughafen - deutsch-dänischen - Werkstatt - Lufthansa-

Maschine-Rucksack

$a \quad$ Der Frankfurter ist einer der größten der Welt.

b Mit meinem Koffer und meinem ging ich weiter zur Autovermietung ...

[...] (Nygård mfl. 2013, s. 174) 
Aufgabe 5c Her manglar slutten. Skriv ferdig setningane:

1. Die Tomaten kommen aus ...

2. Wir kaufen Fleisch bei ...

[...] (Andersen og Bali 2006, s. 184)

I Weitblick 1 er ordene som skal brukes oppgitt i oppgaven, mens i Ankunft 1 er det ikke oppgitt hvilke ord som skal brukes. Førstnevnte oppgave vil derfor være enklere, selv om eleven må forstå betydningen av både ordet og setningen som det skal inngå i, i motsetning til en oppgave hvor eleven skal fylle ut riktig verbform, hvor eleven "bare" må identifisere subjektet i setningen. Oppgaven i Anflug 1 krever i større grad at eleven gjenkaller ord fra minnet eller leter etter ord i læreboka eller i ordbøker og øver i større grad produktive ferdigheter.

Disse oppgaveeksemplene innebærer i forskjellig grad bruk av ord i kontekst. Elevene kan ikke løse oppgavene rent mekanisk, uten å forstå innholdet i setningene. Noen av $\emptyset$ velsene som i større grad er grammatikkøvelser, som for eksempel der eleven skal fylle inn riktig preposisjon eller pronomen, vil kunne resultere i mer mekanisk utfylling. Her er det snakk om gradsforskjeller og det handler også om hvordan oppgavene blir gitt. Det står for eksempel ikke noe i oppgavene om hvilke hjelpemidler elevene skal ha tilgjengelig. Kan de utfordres til å prøve å løse oppgavene uten ordbok og tabeller? Det vil være opp til læreren, da lærebøkene sjelden sier noe om strategibruk i denne sammenhengen.

Andre oppgaver som faller inn under kontekstualisering er parallelltekst, gjenfortelling, definisjon, og bruke bestemte ord i muntlige eller skriftlige aktiviteter. Aufgabe $3 \mathrm{~d}$ i Anflug 1 er et eksempel på en slik oppgave: "Lag fem eigne setningar med eigedomsord. Bruk pilar og fargar" (Andersen og Bali 2006b, s. 166). "Pilar og fargar" viser til eksempler i innledningen til oppgaven hvor en rød pil knytter eiendomsordet til "eigaren" og en svart pil knytter eiendomsordet til "eigedelen". Oppgaven er både ordinnlæring og grammatikk i kontekst. Anflug 1 inneholder også samme typer oppgaver hvor elevene skal bruke ord fra lesetekstene i egne setninger (se f.eks. Aufgabe 1d i Andersen og Bali 2006b, s. 194). I Aufgabe 7 (s. 255) skal elevene bruke noen oppgitte partisippformer av verb i en samtale som hva de gjorde i går. I tekstboka skal elevene skrive et parallelldikt til et dikt om fotball. Diktet skal handle om en sportsgren uten å nevne sportsgrenen (jf. Andersen og Bali 2006a, s. 82). 


\section{Nordic Journal of Modern Language Methodology}

Her er det ikke gitt hvilke ord eleven skal bruke, men eleven vil måtte ta i bruk verb som beskriver aktivitet og andre ord som han eller hun har begynt å lære i arbeidet med kapitlet om sport. Det er også en oppgave som stimulerer til lek med språket og kreative løsninger, framfor fokus på det formelle.

Weitblick 1 inneholder lignende oppgaver. Et eksempel er oppgave 5.17. Boka presenterer et tankekart med ord og uttrykk til emnet hobby og fritid. Oppgaven ser slik ut:

\subsection{Snakke}

Hva gjør du etter skoletid og i helgene? Studer plansjen og forbered deg på å fortelle om dette på tysk til dine klassekamerater. Lag deg en huskelapp om nødvendig. Fem seks stykker setter seg deretter sammen i ring og forteller hverandre på tysk hva de gjør i fritiden. Førstemann stiller spørsmålet: "Was machst du in deiner Freizeit, Ola?" (Nygård mfl. 2013, s. 88).

I denne oppgaven skal elevene bruke ordene i en forberedt muntlig kortpresentasjon, hvor de forteller om seg selv og sine interesser. Elevene får slik brukt ordene i en meningsfull språklig sammenheng og de knytter ordene til sitt eget liv og det de er opptatt av. En annen interessant oppgave finner man på samme side i læreboka. Her er for en gangs skyld målet med oppgaven eksplisitt nevnt:

\subsection{Snakke}

Bruk dialogene som mønster for å lage nye korte dialoger. Målet er å øve inn ord og uttrykksmåter til de sitter. Bli enige om situasjonen, gi hverandre roller og improviser (Nygård mfl. 2013, s. 88).

Dette er en form for parallelltekst hvor elevene lager dialoger etter et oppgitt mønster. Mønsterdialogene det er snakk om er relativt lange tekster i læreboka (jf. Nygård mfl. 2013, s. 81-85). Oppgaven krever stor selvstendighet av elevene gjennom at de selv må lage seg både situasjon og roller. De skal improvisere, det vil si at når det i den første setningen i oppgaven står at de skal lage nye dialoger, betyr ikke det at dialogene skal skrives ned eller forberedes. Elevene skal øve på spontan muntlig interaksjon. Men oppgaven inneholder altså en av de få 


\section{Nordic Journal of Modern Language Methodology}

eksplisitte formuleringene i boka om ordinnlæring: "Målet er å øve inn ord og uttrykksmåter til de sitter" (Nygård mfl. 2013, s. 88). Tanken er at ord og uttrykksmåter skal øves inn gjennom bruk i kontekst. Denne tanken ligger nok også til grunn for mange andre oppgaver, selv om det sjelden blir uttrykt på denne måten.

Det ligger helt tydelig til grunn for formuleringen av oppgaver i de unders $\varnothing \mathrm{kte}$ lærebøkene at ord læres gjennom bruk i kontekst. Begge bøkene har mange øvelser som innebærer en form for kontekstualisering, fra øvelser hvor den språklige konteksten er gitt til $\emptyset$ velser hvor elevene skal skrive og snakke relativt fritt. Øvelsene blir imidlertid bare unntaksvis presentert eksplisitt som ordinnlæringsøvelser og oppgavene legger heller ikke vekt på kontekstualisering som en bevisst strategi elevene kan bruke for å utvide ordforrådet.

\section{Kontrastering og differensiering}

En annen type oppgaver som er forholdsvis mye brukt $\mathrm{i}$ begge lærebøkene er oppgaver i kategorien kontrastering og differensiering. Her er det snakk om arbeid med transparente ord, ortografi og uttale, og ordsalat. Det er snakk om sammenligning med andre språk eleven kan eller sammenligning innenfor målspråket, med fokus på hvordan ord er bygd opp og på gjenkjenning av ordformer.

Nation \& Laufer anbefaler at elevene lærer om transparente ord tidlig i språkopplæringen og at det brukes tid på å lære et stort antall av disse. Elevene vil få mye igjen for innsatsen og vil oppleve mestring og motivasjon (jf. Nation \& Laufer 2012, s. 164). Dette gjelder i stor grad for språk som er så nært beslektet som norsk og tysk, siden antallet transparente ord vil være høyt (jf. Schmitt 1997, s. 209). Både Weitblick 1 og Anflug 1 formidler kunnskap om transparente ord til eleven. Her er et eksempel fra førstnevnte læreverk:

\subsection{Lese og forstå}

Se på bildene og overskriftene. Vi får her høre om tre forskjellige rom som finnes i et hjem. Les de tre småtekstene hver for seg. Mange av de nye ordene du møter er transparente. Det betyr at du ved å sammenligne med norsk, lett skjønner ordets betydning ut fra sammenhengen. Fors $\varnothing \mathrm{k}$ å se for deg hjemmet du får høre om. Lag en gloseliste til alle rommene. (Nygård mfl. 2013, s. 54) 


\section{Nordic Journal of Modern Language Methodology}

I denne oppgaven er fokuset på transparente ord en del av en lesestrategi (elevene skal også se på bilder og overskrifter). Men det er også understreket at elevene skal sammenligne det tyske og det norske ordet. Det er også naturlig at elevene skriver ned noen av disse ordene $\mathrm{i}$ gloselisten de skal lage til rommene. Oppgaven inneholder for øvrig også et element av visualisering, i og med at de skal se for seg hjemmet de leser om.

Som nevnt i avsnittet om repetisjon og memorering inneholder Anflug 1 mange oppgaver som går ut på å lære seg korrekt uttale og rettskriving. Disse oppgavene hører delvis til under kontrastering og differensiering, spesielt der det er snakk om å kunne skille ord som har alle lyder til felles bortsett fra en (såkalte minimalpar) og oppgaver som fokuserer på forholdet mellom skrift og uttale, og på rettskrivningsregler. I Weitblick 1 er det ingen slike oppgaver, men det er en egen del om "Tysk uttale og rettskriving" i minigrammatikken bak i boka (Nygård mfl. 2013, s. 280-282). Her står også fem eksempler på "Zungenbrecher" i margen. Under lydskrift blir de tyske lydene i mange tilfeller sammenlignet med engelsk og norsk. Lydene i tysk blir her representert gjennom lydskrift, men lydskrift blir ikke brukt noe annet sted i boka for å indikere uttale, for eksempel i gloselistene.

Når det gjelder strategibruk, gjelder det oppsummeringsvis for begge lærebøkene at elevene oppfordres til å være oppmerksomme på den store mengden transparente ord i tysk i møte med ukjent tekst.

\section{Visualisering og assosiering}

Det er få visualiserings- og assosieringsoppgaver i de to undersøkte lærebøkene. Flere av visualiseringsoppgavene omhandler også emner som vanskelig kan behandles uten noen form for visualisering, for eksempel når man skal snakke om farger eller hva klokka er. Familierelasjoner blir framstilt ved hjelp av en plansje i Anflug 1 (jf. Andersen og Bali 2006b, s. 81).

En annen type oppgave i begge lærebøkene er bildebeskrivelse, som også inneholder et element av kontekstualisering. Det er også noen få eksempler på oppgaver som går ut på å kombinere ord og bilde. For eksempel i Anflug 1 hvor en illustrasjon viser en datamaskin med tilbehør og oppgaven er å koble riktig ord fra en liste til illustrasjonen (jf. Aufgabe $1 \mathrm{i}$ Andersen og Bali 2006b, s. 244). Men bilder blir brukt i liten grad i forbindelse med 


\section{Nordic Journal of Modern Language Methodology}

ordinnlæring. Bilder blir i større grad brukt enten som lesestøtte eller som utgangspunkt for skriving.

Lærebøkene har i veldig liten grad oppgaver hvor elever selv skal visualisere eller assosiere. Det er noen unntak. Anflug 1 har for eksempel denne deloppgaven (ordet Menschenalphabet viser til en liste med menneskelige egenskaper): "Vel tre eigenskapar frå "Menschenalphabet" og demonstrer dei. Du kan for eksempel mime eller teikne" (Aufgabe 2 i Andersen og Bali 2006b, s. 56).

Assosiering blir til en viss grad brukt i arbeid med uttale ved hjelp av såkalte Zungenbrecher. Som nevnt ovenfor er det ikke konkrete oppgaver knyttet til disse i Weitblick 1, men Anflug 1 har noen slike (jf. f.eks. Aufgabe 2b i Andersen og Bali 2006, s. 93). Rim og regler finnes det noen få eksempler på i forbindelse med innlæring av grammatikk, men ikke i oppgaver som handler om ordinnlæring.

Det ingen av bøkene har, er oppgaver som går ut på å se for seg bilder i sinnet for å merke seg ord og uttrykk. Keyword-metoden er et eksempel. Den går ut på at man forbinder et bilde for betydningen av ordet man vil lære med et bilde for å huske uttalen. Dette kan man visualisere i sinnet eller man kan lage en illustrasjon. Det er grunn til å anta at et slikt mentalt arbeid vil føre til dypere prossesering av ordene som skal læres (jf. Sökmen 1997, s. 247).

En annen metode er locimetoden hvor man visualiserer de ordene man skal lære seg på et bestemt sted. Nært beslektet er reiserutemetoden hvor man visualiserer ordene langs en reiserute. Det går også an å lage seg fortellinger med de ordene man vil lære, eller å assosiere ordene med personlige erfaringer og opplevelser. Dette bare for å nevne noen av de visualiseringsøvelsene man kunne bruke i en lærebok (jf. Schmitt 1997, s. 213; Sökmen 1997, s. 244; Tornberg 2015, s. 136).

I tillegg til at det er få oppgaver hvor elevene skal ta i bruk visualisering og assosiering, presenterer ingen av lærebøkene visualisering og assosiering som strategier elevene kan benytte seg av for å lære nye ord. Det blir ikke eksplisitt sagt at dette kan være en lur (og morsom) måte å lære ord på.

\section{Strukturering}

Begge lærebøkene inneholder flere struktureringsoppgaver enn både repetisjon- og memoreringsoppgaver og visualiserings- og assosiasjonsoppgaver. Struktureringsoppgaver 


\section{Nordic Journal of Modern Language Methodology}

handler om å sortere ord ut i fra forskjellige kriterier. Å organisere ord på denne måten kan gjøre det lettere å huske dem (jf. Schmitt 1997, s. 213-214). Det er fordi strukturering er en strategi som krever dypere og rikere prosessering av ord, ved at eleven unders $\varnothing$ ker ulike sammenhenger til andre ord (jf. Sökmen 1997, s. 242-243).

Her følger et eksempel fra Weitblick 1. Eleven blir presentert for 30 substantiv hulter til bulter:

\subsection{Skrive}

Samle ordene som naturlig hører sammen i to hovedgrupper. Noen av ordene hører kanskje hjemme i begge gruppene? Vær sikker på hva alle ordene betyr. Lag setninger med ordene, enten to og to muntlig eller på egen hånd skriftlig. (Nygård mfl. 2013, s. 192)

Det blir ikke sagt rett ut, men siden det er snakk om ord som "naturlig" hører sammen og elevene blir bedt om å forsikre seg om hva ordene betyr, ligger det an til at elevene skal tenke semantisk strukturering i denne oppgaven. Oppgaven har to trinn, først skal elevene jobbe med enkeltordene, før de skal bruke dem i en sammenheng.

I Anflug 1 finner vi denne oppgaven. Tabellen det blir referert til har kolonneoverskriftene "Familie", "Farben", "Orte" og "Schreibtisch". Ordene elevene skal organisere er 16 substantiver og adjektiver:

\section{Aufgabe 1c}

Set orda som etter innhaldet høyrer saman, i grupper med fire ord i kvar gruppe. Skriv dei i tabellen på neste side. Du vil merke at det er lettare å hugse orda med dette systemet. (Andersen og Bali 2006, s. 108)

Det er igjen snakk om semantisk organisering. Det som imidlertid er mest interessant i denne oppgaven er at den blir presentert som en ordinnlæringsstrategi: "Du vil merke at det er lettare å hugse orda med dette systemet". Eleven blir riktignok i liten grad oppfordret til metakognisjon, siden læreboka evaluerer strategien for eleven, men eleven blir oppfordret til å se øvelsen som en strategi for å huske nye ord bedre. Lærebøkene har imidlertid svært få 


\section{Nordic Journal of Modern Language Methodology}

formuleringer av denne typen, så det er ikke grunnlag for å hevde at dette er en del av et større fokus på strukturering som ordinnlæringsstrategi.

\section{Metakognitive strategier}

\section{Organisere og planlegge}

Planlegging av ordinnlæring handler om å bestemme seg for hvilke ord eller hvilke aspekter ved ord man skal fokusere oppmerksomheten på, hvordan man skal fokusere oppmerksomheten (altså hvilke strategier man skal bruke) og hvor ofte man skal fokusere oppmerksomheten på et ord eller en gruppe med ord (planlegging av repetisjon) (jf. Nation 2012, s. 218-219).

I de undersøkte lærebøkene blir elevene i svært liten grad oppfordret til å organisere og planlegge ordinnlæringen. Weitblick 1 inneholder én formulering som kan tolkes i denne retningen. I oppgave 10.13 skal elevene lage et rollespill. De får beskrevet en situasjon og rollene de skal spille og får beskjed om å ta i bruk mønster de tidligere har $\emptyset v d$ inn. Til slutt stiller oppgaven spørsmålet: "I tillegg har du kanskje bruk for å lage en gloseliste?" (Nygård mfl. 2013, s. 176). Dette kan forstås som en oppfordring til eleven om å ta ansvar for litt av planleggingen selv. Samtidig er dette ikke først og fremst en ordinnlæringsoppgave og som spørsmålet antyder, kan gloselisten kuttes ut. I Anflug 1 blir det heller ikke lagt vekt på organisering og planlegging, bortsett fra et par oppgaver i forbindelse med ordbokbruk, hvor elevene for eksempel blir oppfordret til å lære seg tyske substantiv med bestemt artikkel og flertallsendelse (Aufgabe 3 og 6b i Andersen og Bali 2006b, s. 41 og 118).

\section{Evaluere læringsutbytte og læringsmetoder}

Anflug 1 inneholder et spørreskjema om læringsstiler: "Siktemålet med dette spørreskjemaet er at du skal finne ut noko om kva læringsstil du helst vil velje når du arbeider med informasjon. Du har truleg ein læringsstil som du automatisk gjer deg nytte av når du skal "ta inn" og "ta ut" kunnskap" (Andersen og Bali 2006b, s. 31). Læringsstiler og læringsstrategier er i utgangspunktet to forskjellige ting, men når man snakker om læringsstiler som en framgangsmåte eleven kan velge når han eller hun arbeider med informasjon, er vi innenfor det vi i denne undersøkelsen kaller læringsstrategier. Læreboka understreker flere ganger at det er slik begrepet læringsstil skal forstås i denne sammenhengen: "Testresultatet viser 


\section{Nordic Journal of Modern Language Methodology}

korleis du helst vil lære, det seier ingenting om dei sterke og svake sidene dine", og videre: "Testen fortel deg korleis du helst vil lære. Når du veit det, vil du vere i stand til å velje den læringsstilen som kan gi deg best resultat" (Andersen og Bali 2006b, s. 35-36). Spørreskjemaet gjelder læringsstiler generelt, men er relevant for alle aspekter innenfor språklæring, også ordinnlæring.

Spørreskjemaet inneholder 13 spørsmål med svaralternativer. Svarene skal hjelpe elevene å avgjøre om de foretrekker å lære visuelt, auditivt, gjennom å lese og skrive, eller kinestetisk. Læreboka presenterer så noen praktiske råd til hva elevene kan gjøre ut i fra hvilken læringsstil de foretrekker. De praktiske rådene er til en viss grad anvendbare innenfor ordinnlæring. "Den visuelle" blir oppfordret til å bruke symboler, bilder, illustrasjoner osv. "Den auditive" blir oppfordret til å diskutere med medelever og lærere, og forklare de den har lært. "Den lese/skrive-orienterte" kan blant annet skrive lister og definisjoner, mens den kinestetiske bør ifølge læreboka bruke rollespill så mye som mulig, og kombinere læring med bevegelser og Øvelser (Andersen og Bali 2006b, s. 31-36).

Spørreskjemaet blander som sagt sammen begrepene læringsstiler og læringsstrategier. Slik begrepet læringsstil brukes her, må dette forstås som en oppgave som handler om læringsstrategier. Elevene skal tenke over hvilke strategier de foretrekker og oppfordres til å være bevisste på hvilke strategier de tar i bruk framover, og slik sett er dette spørreskjemaet arbeid med metakognitive læringsstrategier. Det er altså en tanke i Anflug 1 at elevene skal være bevisste på hvordan de lærer og på hvilke strategier de tar i bruk. Man kan imidlertid spørre seg hvor stort fokuset blir på dette, hvis det blir tatt opp bare en gang i en bok på nesten 300 sider, og ikke blir fulgt opp utover i boka. Sökmen (1997) har eksempler på spørsmål til en spørreunders $\varnothing$ kelse som er rettet mot elevens bruk av ordinnlæringsstrategier. Spørsmålene er formulert slik at eleven skal ta stilling til hvilke ordinnlæringsstrategier som virker for ham eller henne (jf. Sökmen 1997, s. 256). Man kunne tenke seg en lærebok hvor oppgavene eksplisitt oppfordret elevene til å velge mellom strategier, eller hvor de blir bedt om å vurdere kvaliteten av strategier.

\section{Konklusjon}

Den gjeldende, men snart utgående læreplanen i fremmedspråk nivå I omtaler ordinnlæring i forbindelse med bruk av ord i kontekst. Slik sett er det ikke overraskende at de undersøkte 


\section{Nordic Journal of Modern Language Methodology}

lærebøkene har et fokus på kontekstualiseringsoppgaver. Et funn i denne undersøkelsen er at disse oppgavene ikke alltid er gode ordinnlæringsoppgaver. Mange av dem er lukeutfyllingsoppgaver som kan føre til et mekanisk arbeid fra elevens side, som ikke fører til den ønskede dybden i bearbeidelsen av ordene. Undersøkelsen peker også på at kontekstualiseringsoppgavene ikke blir presentert som strategier for å lære nye ord. De blir presentert som for eksempel øvelser i skriving eller muntlig aktivitet. Oppgavene representerer derfor ikke et fokus på ordinnlæring, og i enda mindre grad på ordinnlæringsstrategier. Et annet viktig funn er forholdet mellom repetisjon og memorering og kontekstualisering. Utsagnene, spesielt i Weitblick 1, som ber elevene om å lære, Øve inn, osv. står som regel i en oppgavekontekst hvor neste steg er en eller annen form for bruk av de innlærte ordene. Oppgaveformuleringene kan altså tyde på to ting: for det første det nevnte fokuset på bruken av ord i kontekst, for det andre ses her repetisjon som den naturlige måten å lære inn ord på i første del av ordinnlæringsprosessen, så naturlig at elevene ikke trenger å få presentert strategier for dette. Det at lærebøkene inneholder så få eksempler på visualiserings- og assosiasjonsoppgaver, og struktureringsoppgaver forsterker dette inntrykket.

Anflug 1 har et litt større innslag av bevisst arbeid med språklæringsstrategier generelt enn Weitblick 1, men dette er lite gjennomført når det gjelder ordinnlæring. Spørreundersøkelsen som gjelder læringsstiler burde ha vært fulgt opp av en presentasjon av forskjellige ordinnlæringsstrategier i mange oppgaver utover i boka og elevene burde også blitt oppfordret til å gjøre egne vurderinger i forbindelse med ordinnlæring.

En innvending mot denne undersøkelsen er at lærebøkene ikke er laget for selvstudium, men for bruk i klasserommet med en kvalifisert lærer. Men dette hindrer ikke lærebøkene i å ha fokus på læringsstrategier i forbindelse med lesing, både før, under og etter lesingen. Ovenfor ble også en studie av Haukås mfl. nevnt, som viser at mange lærere ikke føler seg kompetente til å arbeide med språklæringsstrategier (jf. Haukås mfl. 2016). Det er enda et argument for at lærebøkene burde være eksplisitte på dette området, også når det gjelder ordinnlæring. Faren er at ordinnlæringen at eleven blir overlatt til seg selv på dette området og griper til metoder som ifølge forskningen ikke nødvendigvis er de mest effektive. Å gi elevene lister med ord som de skal lære seg selv hjemme, for så å ta en gloseprøve på skolen, er fremdeles det mange forbinder med ordinnlæring i dag. Dette er synd, siden ordinnlæring er en mangfoldig og sammensatt prosess. 


\section{Nordic Journal of Modern Language Methodology}

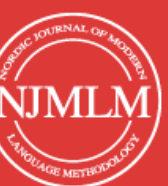

2019, 7 (1), 84-115 (Part B - Not peer reviewed)

Denne teksten begynte med en personlig vinkling på problemstillingen. La meg avslutte med den fiktive historien til en elev som har lært om glemselskurven til Ebbinghaus (det står en kort tekst om den i den fiktive læreboka), fått opplæring i bruk av Spaced Repetition Sofware, og som foretrekker å bruke visualiseringer når han støter på ord han synes er vanskelige å lære seg:

Jeg har lagret 21 nye ord som jeg skal begynne å lære denne uka. Jeg har stilt inn appen slik at den presenterer tre nye ord hver dag. Jeg synes det er nok. Det er mange i klassen som har flere. Og noen har bare ett ord om dagen. I tillegg til de nye ordene har jeg 34 ord som skal repeteres i dag. Noen av ordene begynte jeg å lære for flere måneder siden, andre så jeg sist for et par dager siden. Jo bedre jeg klarer å huske et ord, jo sjeldnere trenger jeg å repetere det. "Die Sehenswürdigkeit" trenger jeg ikke å se igjen før om tre uker. Hvordan skal jeg huske at "die Schuppe" kan bety både flass og fiskeskjell? Jeg kan se for meg at jeg koker fiskesuppe på kjøkkenet og flasser oppi suppa. Suppe - Schuppe. Ekkelt! Men jeg husker det. Det tar bare fem minutter å gå igjennom alle ordene. Jeg gjør det alltid på bussen på vei til skolen. Den flassende fiskesuppekokende kokken kan være mitt bidrag på forumet denne uka. Det kan kanskje funke for noen andre også. Jeg har ikke helt skjønt hvordan jeg skal huske kjønn ennå. Det kan jeg spørre om. Kanskje noen har et tips.

\section{Litteratur}

Aitchison, J. (1996). Taming the wilderness. Words in the Mental Lexicon. I G. Anderman \& M. Rogers (red.), Words, Words, Words. The Translator and the Language Learner (1526). Clevedon: Multilingual Matters Ltd.

Andersen, E. F. \& Bali, B. (2006a). Anflug 1: Textbuch. Oslo: Cappelen Forlag. Andersen, E. F. \& Bali, B. (2006b). Anflug 1: Arbeitsbuch. Oslo: Cappelen Forlag.

Baddeley, A.D. (1990). Human Memory. Theory and Practice. Needham Heights. MA: Allyn and Bacon.

Bjørke, C., Dypedahl, M. \& Haukås, Å. (red.) (2018). Fremmedspråksdidaktikk. Oslo: Cappelen Damm Akademisk.

Carter, R. \& McCarthy, M. (1988). Vocabulary and Language Teaching. London: Longman.

Craik, F.I.M. \& Lockhart, R.S. (1972). Levels of processing: A framework for memory research. I Journal of Verbal Learning and Verbal Behavior, nr 11(6), (671-684).

Craik, F.I.M. \& Tulving, E. (1975). Depth of processing and the retention of words in episodic memory. I Journal of Experimental Psychology: General nr. 104, (268-294).

Davis, P. \& Kryszewska, H. (2012). The Company Words Keep. Peaslake: Delta Publishing.

Gardner, H (1993). Creating Minds. New York: Basic Books. 
Gausland, A. \& Haukås, Å. (2011). Bruk av ordinnlæringsstrategier blant norske tyskelever. Acta Didactica, 5(1), art. 3. Hentet fra https://journals.uio.no/index.php/adno/article/view/1064

Golden, A. (2014). Ordforråd, ordbruk og ordinnlaering (4. utg.). Oslo: Gyldendal Akademisk.

Haukås, Å. (2011). Læringsstrategiar i språkundervisninga. Bedre skole, 23(2), (38-42).

Haukås, Å. (2012). Lærarhaldningar til språklæringsstrategiar. Norsk Pedagodisk Tidsskrift, 96(2), (114-128).

Haukås, A. (2015). A Comparison of L2 and L3 Learners' Strategy Use in School Settings. I Canadian Modern Language Review. Vol.71(4) (383-405).

Haukås, Å., Malmqvist, A. \& Valfridson, I. (2016). Sprachbewusstheit und Fremdsprachenlernen. Inwiefern fördert die Grammatik in skandinavischen DaFLehrwerken die Sprachbewusstheit der Lernenden? I Zeitschrift für Interkulturellen Fremdsprachenunterricht. Vol.21(2), (13-26).

Henriksen, B. (1995). Hvordan husker man ord? I Sprogforum, 3, (45-55).

Hirsch, D. (red.). (2012). Current Perspectives in Second Language Vocabulary Research. Bern: Peter Lang.

Lightbown, P.M. \& Spada, N. (2013). How Languages are Learned (4. utg.). Oxford: Oxford University Press.

Melka, F. (1997). Receptive vs. productive aspects of vocabulary. Schmitt, N. \& McCarthy, M. (red.). Vocabulary. Description, Acquisition and Pedagogy (84-102). Cambridge: Cambridge University Press.

Morfeld, P. (1998). Wissend lernen= effektiver lernen?: Vokabellerntraining im Anfängerunterricht Englisch an der Volkshochschule. Tübingen: Gunter Narr Verlag.

Nagy, W. (1997). On the role of context in first- and second language vocabulary learning. I Schmitt, N. \& McCarthy, M. (red.). Vocabulary. Description, Acquisition and Pedagogy (64-83). Cambridge: Cambridge University Press.

Nation, P. (2001). Learning Vocabulary in another Language. Cambridge: Cambridge University Press.

Nation, P. (2013). Vocabulary Learning and Teaching. I P. Robinson (red.), Routledge Encyclopedia of Second Language Acquisition (682-686). New York: Routledge.

Nation, P. \& Laufer, B. (2012). Vocabulary. I S. Gass \& A. Mackey (red.), The Routledge Handbook of Second Language Acquisition (163-176). New York: Routledge.

Nygård, T., Skorge, K., Thesen, H. og Biesalski, P. (2013). Weitblick. Tysk nivå 1. Oslo: Aschehoug.

Oxford, Rebecca (1990). Language Learning Strategies: What Every Teacher Should Know. Boston: Heinle \& Heinle.

Schmitt, N. (1997) Vocabulary learning strategies. I Schmitt, N. \& McCarthy, M. (red.). Vocabulary. Description, Acquisition and Pedagogy (199-227). Cambridge: Cambridge University Press.

Schmitt, N. \& McCarthy, M. (red.) (1997). Vocabulary. Description, Acquisition and Pedagogy. Cambridge: Cambridge University Press.

Sökmen, A. (1997). Current trends in teaching second language vocabulary. I Schmitt, N. \& McCarthy, M. (red.). Vocabulary. Description, Acquisition and Pedagogy (237-257). Cambridge: Cambridge University Press. 


\section{Nordic Journal of Modern Language Methodology}

Sweeney, C.A. \& Bellezza, F.S. (1982). Use of Keyword mnemonics in learning English vocabulary. Human Learning 1, (155-163).

Stæhr, L.S. (2015). Ordforrådtilegnelse - fundamentet for kommunikativ kompetanse. I A.S. Gregersen (red.), Sprogfag i forandring (169-200). Fredriksberg: Samfundsliteratur. Tornberg, U. (2015). Språkdidaktik. Malmö: Gleerups.

Utdanningsdirektoratet. (2006). Lareplan i fremmedspråk. Hentet fra https://www.udir.no/k106/FSP1-01 